\title{
Economic Development in Indonesia:
}

\section{The Integrated Model of Islamic Financial Inclusion}

\author{
Laila Masruro Pimada \\ Magister of Islamic Economics Science \\ Airlangga University \\ Surabaya, Indonesia \\ masruropimada@gmail.com
}

\author{
Novelinda Nurul Firdaus \\ Magister of Islamic Economics Science \\ Airlangga University \\ Surabaya, Indonesia \\ novelindanf@gmail.com
}

\begin{abstract}
The purpose of this paper is to examine the importance of cooperation between government institutions, financial institutions and non-profit organisations in order to succeed at the financial inclusion agenda. The qualitative and descriptive approach with library research was used as the methodology. Within the spirit of Islamic economic development, the authors have proposed a new model called: The Integrated Model of Islamic Financial Inclusion. The model provides a whole new concept about realising inclusive development: progrowth, pro-job, pro-poor, and pro-environment. The implementation of this model is expected to overcome poverty and inequality problems in Indonesia, so that economic growth can be improved.
\end{abstract}

Keywords- Financial Inclusion; Amil Zakat Institution; Islamic Economic Development

\section{INTRODUCTION}

Economic development is one of the most important agendas that must be planned and realised by a country considering the importance of its use as an indicator in measuring the country's economic performance. Indonesia has been independent since 1945, and has experienced ups and downs in terms of economic growth and development. After the financial crisis in 1998, Indonesia performed various transformations in their economic, social and political views. "Inclusive" is a new concept of Indonesian economic development (Tambunan, 2015). The Indonesian government has applied several strategies in order to achieve inclusive development namely pro-growth, pro-job, pro-poor, and proenvironment. Naturally, when the government implements 'pro-poor', 'pro-growth' and 'pro job' policies, it is not only on how to implement but also how to establish a development strategy for reducing poverty through economic growth that is important (Farwati, 2012).

Financial inclusion is an important element in the inclusive development concept, since empirically there is a positive influence given by the financial systems' functions in longterm economic growth (Levine, 2005). At the G20 Toronto Summit held in June 2010, global leaders pledged to support financial inclusion to reduce poverty in the world. Furthermore, the Government of Indonesia strongly believes that improving access to finances and improving the use of financial services will raise people's welfare (Tambunan, 2015). However, Indonesia still has not experienced significant financial inclusion growth, particularly in the financial institution sector. Setiawan (2015) disclosed that Indonesia, compared with ASEAN countries and other countries, had relatively few banking offices, limited ATM machines and low formal account access due to the absence of money to be put in to the account.

In order to ensure the sustainability and effectiveness of financial inclusion, it requires good coordination and collaboration between the various committed parties, such as Bank Indonesia, the Financial Services Authority, banking, non-bank financial institutions, education ministries, private sector, business associations and other non-profit organisations (Tambunan, 2015). Indonesia makes religion a strong social capital in a society, which has become the glue of individuals in a collectively-articulated value system (Latif, 2008). The thought of having amil zakat institutions already existed 13 centuries ago (Karim and Syarief, 2008). The Amil Zakat Institution is a non-profit organisation which has a similar purpose to the Government in terms of economic development.

Noawadays, Amil Zakat institutions have become an important organisation in Indonesia regarding the majority of the Muslim population. However, there is the problem of public distrust of Amil Zakat institutions. The media reported that there were demonstrations conducted by thousands of teachers in East Lombok, West Nusa Tenggara who disagreed with the government's zakat withdrawal mechanism due to their doubts about their ability in relation to zakat management (Sujatmiko, 2005). Therefore, the following models have been proposed by the authors in order to achieve economic development through Islamic financial inclusion involving the government, banking institutions and Amil Zakat Institutions.

\section{LITERATURE REVIEW}

\section{A. Economic Development of Indonesia}

One of the most important indicators in analysing the economic development occurring in a country is economic growth. Economic development and economic growth have different meanings. Economic development is generally defined as a process that causes a long-term increase in the real income per capita of a country's population that is accompanied by an institutional system. Economic growth is 
defined as an increase in GDP or GNP regardless of whether or not the increase is greater or lesser than the rate of population growth, or whether changes in economic structure occur or not (Arsyad, 1999: 11,13). Furthermore, Schumpeter in Jhiang (2013) disclosed that the in relation to the usual difference between economic growth and economic development, economic growth refers to developed countries whereas economic development refers to developing countries. According to Baran (1973) in Huda et al (2015: 2), both growth and economic development equally impresses a shift to something new from something that has long been used.

Indonesia, which is part of the United Nations, has a strategy that complies with the Millennium Development Goals (MDGs) declaration agreed by 189 UN countries at the 2000 Millennium Summit in New York. The strategies taken up by Indonesia in the framework of the country's economic development are contained in the Master Plan of Acceleration and Expansion of Indonesian Economic Development (MP3EI). They are pro-growth, pro-job, pro-poor and proenvironment. Based on Presidential Regulation number 48 2014: Realising an Independent Indonesian Community, Advanced, Fair, and Prosperous. There are three missions that have become the main focus in the framework of the Acceleration and Expansion of Economic Development Indonesia long-term (2005-2025) namely: 1) The expansion of the value chain of the production process as well as the distribution of asset management and access (potential) of Natural Resources, geographic area, and Human Resources (HR), through the creation of integrated and synergic economic activities within and between growth centres and economy; 2) Encouraging the improvement of production efficiency and marketing as well as domestic market integration in order to strengthen the competitiveness and endurance of the national economy and 3) Encouraging the strengthening of national innovation systems on the production, process, and marketing sides for the strengthening of sustainable global competitiveness, towards an innovationdriven economy.

Thus, the change from the exclusive government to the inclusiveness adopted by the Indonesian government (Tambunan, 2015) is included in order to build the country's economy. It is known that economic development is not only focused on increasing the income per capita, but also Indonesia through its long-term plan has made developments in various ways, namely to tackle poverty and hunger, to achieve basic education for all, to promote gender equality and to empower women, to reduce child mortality, increase maternal health, combating HIV and AIDS, preserving the environment and building global partnerships (Huda et al., 2015: 11-14). However, Indonesia is still ranked 9th out of 33 countries recorded in the Basic Statistics Asia Development Bank 2016. In this case, Indonesia has been defeated by neighbouring countries such as Malaysia, Vietnam and Thailand. The Indonesian government should be motivated and continue to make improvements by maximising the role of the Indonesian people in helping in the economic development of Indonesia.

\section{B. Financial Inclusion}

After the Asian financial crisis of 1997-1998, Indonesia changed its national development strategy in all areas, including in the financial sector from an "exclusive" orientation to an even more "inclusive" one. Tambunan (2015) explained that the country has good reason to adopt financial inclusion as the new national development policy objective, given that (i) the financial sector is highly concentrated, that is, dominated by banks (most profitably, with low levels of intermediation) with growing capital markets, although they are still concentrated in some large companies, and the low penetration of pensions, insurance, and other non-bank financial institutions; (ii) only a small fraction of the total population of Indonesia has access to banking services and (iii) poverty is a serious problem in Indonesia.

Beik and Arsyanti (2016: 222) revealed the positive effects that will be felt by society with financial inclusion: 1) have savings recorded in formal financial institutions; 2) access financing from formal financial institutions; 3) interact and utilise the products offered by formal financial institutions; 4) share and contribute from and to the community and 5) to improve the ability of soft skills and hard skills. Financial inclusion in Indonesia was launched in 2010. Bank Indonesia launched the National Strategy for Financial Inclusion (NSFI) program in an effort to expand public access to financial services. So far, $32 \%$ or 76 million people have not been touched by financial services (financial exclusion). In addition, 60-70\% of Micro, Small and Medium Enterprises (MSMEs) do not have access to banks. Whereas nearly 53 million poor people working in the MSME sector have the enormous potential to reduce unemployment and reduce poverty (Nengsih, 2015).

The research of the Financial Services Authority (OJK) in 2013 through a survey in 20 provinces with 8,000 respondents, revealed the relatively low literacy (understanding) of Indonesian finance. This condition is in line with the low level of citizen's financial inclusion. In terms of literacy, the public's understanding of banking is about 22 percent, insurance services 18 percent, pawnshops 15 percent, financing institutions 7 percent, and capital markets 4 percent. These results contain the message that there is no other option for the Indonesian population except to create programs and policies to improve an access to finances for the poor, i.e. programs and policies that can be a solution for poor households who have difficulty in obtaining credit support from formal financial institutions.

\section{The role of Amil Zakat Institution in Indonesia}

The history of the emergence of the Amil Zakat Institution in Indonesia has been initiated since 13 centuries ago (Karim and Syarief, 2008), when Islam began to enter Indonesia. Step by step, society in various regions has begun to recognise, understand and finally practice Islam. The practice of zakat management is still very simple and natural. After passing the phase of zakat management individually, Muslims in Indonesia realise the need to improve the quality of zakat management. People have begun to feel the need for zakat management institutions, infaq and alms. The drive to institutionalise the management of zakat continues to 
strengthen. This strong desire crystallised with the suggestion by eleven scholars of a national level to President Soeharto on 24 September, 1968.

Various regulations illustrate the government's concern for this non-institution. As explained by Latief (2008), several studies on social movements and development show that the emergence of Civil Society Organisations (CSO) are driven by social, economic and political conditions in which states / governments are incapable, less eager, negligent, not serious or there are many limitations in preparing and implementing the development programs. Such conditions ultimately lead to the growth of independent organisations as the collective responses of society. Thus, it is no wonder that there are too many Amil Zakat Institutions in Indonesia due to the lofty desire of the community to build Indonesia up through the implementation of good zakat considering that the economic gap is still high in Indonesia.

\section{RESEARCH METHODOLOGY}

The research methodology used in this study is the descriptive qualitative method based on library research. According to Zed (2004: 2-3), library research is a series of activities related to library data collection methods, including reading and recording and processing material research. It is a study that utilises the source library to obtain the research data.

\section{RESUlT AND DisCUSSION}

In order to help maximise the financial inclusion program towards the equitable distribution of sustainable economic development, synergising the role of organisational nomenclature consisting of state governments, private institutions and non-profit organisations (Latief, 2008), and in the context of realising good coordination and collaboration among stakeholders to ensure the sustainability and effectiveness of the program, the authors have proposed a model of Islamic financial inclusion. It is said to be Islamic because the non-profit institution proposed in this model is an Islamic philanthropy institution that is the Amil Zakat institution. In relation to the proposed model, the private institutions (engaged in finance) have been invited to collaborate in an institution based on Islam as well, namely sharia banking. The Indonesian government was also invited to collaborate in the model in order to jointly lead to financial inclusion that encourages economic development within the framework of the Unitary State of the Republic of Indonesia (NKRI) which recalls the country's development strategy that is similar to the function of the distribution of zakat itself, which is pro-poor.

In addition, this model was made with the consideration of financial efficiency between the three institutions chosen in the model. For example, the Amil Zakat Institution will be more economical if it is supported by technical assistants related to expertise in productive zakat (experts in various areas of SMEs) and to get assistance from sharia banking in the case of financial advisors (which can be done through the sharia bank CSR program). From the side of sharia banking, in addition to the completion of CSR's liabilities, sharia banking will get feedback in the form of increasing the number of its customers and sustainable SME entrepreneurs will be able to access financing in the scheme of cooperation owned by sharia banks. This means that this model clearly contains the function as a financial inclusion. As for the Ministry of Cooperatives and SMEs, with cooperation, they will get benefits from the existence of new funding sources that will arise from the assistance of Amil Zakat Institutions. This is so that the strategic plan of the Ministry of SMEs in the form of SME empowerment can be fulfilled even more than the help that has been formed in this model. Finally, inclusive country development with pro-growth, pro-job, pro-poor and proenvironment strategies can be achieved. The shariah-based financial model can be seen in Figure 1.

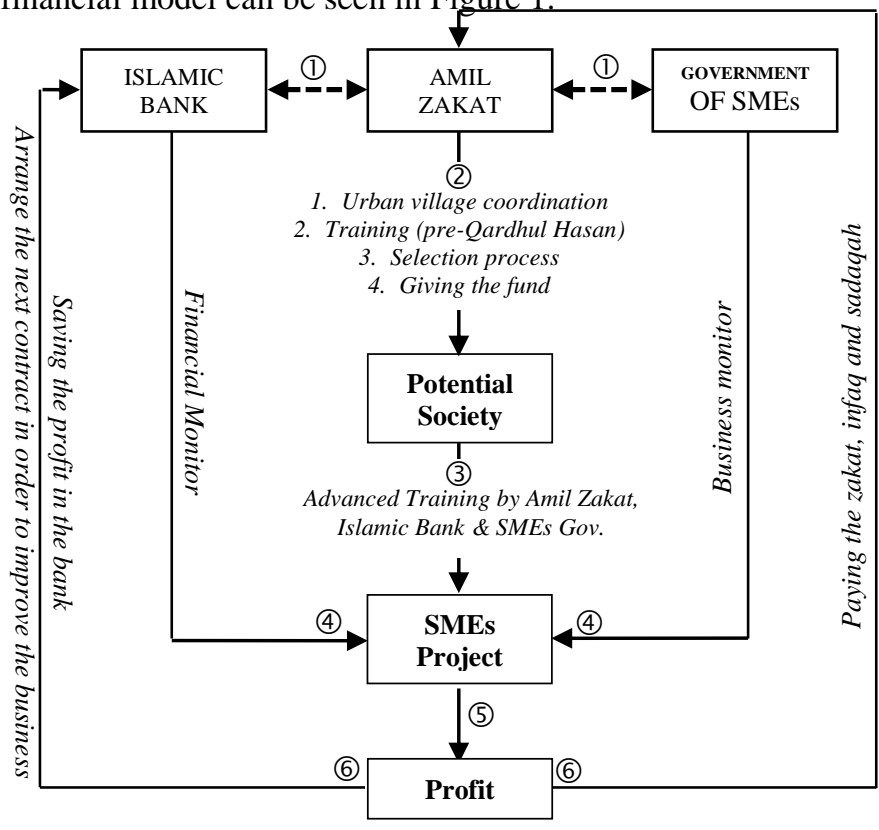

Figure 1. The Integrated Model of Islamic Financial Inclusion

Further explanations about Figure 1 are in the following discussion.

\section{A. The role of Zakat Institution in Islamic Financial Inclusion Model}

As a non-profit organisation that grew out of the movement of the spirit of society, the Institute of Amil Zakat (LAZ) keeps a high social value indicated through the building of programs. Karim and Syarief (2008) conveyed that there are too many LAZs in Indonesia. This is not just a trend, but it is also because of noble ideals. By referring to the Quran Surah At-Taubah verse 60, the Amil Zakat must understand that the distribution of zakat is destined for the eradication of poverty. This is clearly in line with the Indonesian government's strategy on pro-poor points. The importance of LAZ's role in this model is for the sustainability of the professionalism of LAZ itself considering that there is still public distrust in the performance of LAZ which is marked by the small amount of zakat collected nationally compared to the potential that should be obtained. It has only collected $1 \%$ of the total potential of 217 trillion rupiah (BAZNAS, 2013). 
In addition, Firmansyah (2013) revealed that the low realisation of zakat is due to the knowledge of the people on the sources of treasures which are the object of zakat still being limited to the conventional sources as stated in the Qur'an and hadith. The sources of zakat must be zoned in accordance with the development of modern economy and is now growing its business. Secondly, the failure in the management of zakat in the past still leaves people with distrust in the zakat collection agencies. As a result, many of the people still maintain the traditional pattern of zakat distribution, which is the distribution of zakat directly by muzakki to individuals who are considered entitled to receive it.

The role of LAZ in this model can be maximised through its function as zakat collector and distributor. When zakat funds are collected from the community, LAZ needs to find data in the field through coordination with lower level government to find the people who belong to the category who are entitled to receive zakat. Once the data is collected, the LAZ should collect the potential recipients of zakat (mustahik) in groups that are conducive to training. The training provided is fundamental knowledge-based training on zakat including productive zakat, financial inclusion and MSME. Of course, this training is held in cooperation with the three institutions that have been proposed in the above model. This training is aimed at capturing communities that have the potential to be empowered within the framework of the above model.

\section{B. The Role of the Ministry of Cooperatives and SMEs in the Islamic Financial Inclusion Model}

The Ministry of Cooperatives and Small Medium Enterprises (SMEs), in particular the working cabinet 20152019, has a vision and mission to accompany the extraordinary economic developments in Indonesia. Based on the Strategic Plan Document of the Ministry of SMEs, the purpose of the SMEs Ministry is to realise competitive SMEs and to contribute to the improvement of the national economy and people's welfare based on entrepreneurship spirit and integrity. This objective then becomes the basis for the establishment of Strategic Goals of the Ministry of Cooperatives and SMEs in 2015-2019. The achievement of these objectives is carried out through the following efforts: 1) Increasing the competence of MSMEs in entrepreneurship and innovation, production techniques and business management, as well as marketing at home and abroad; 2) Increasing the independence of cooperatives through the strengthening of their identity; 3) Increasing the scope, scheme and quality of cooperative and SME-supporting services related to training, financing, business assistance, technology, information services, market intermediation and partnerships; 4) Strengthening of cooperatives in the utilisation of local resources in various economic sectors, and social and economic layers of the community; 5) Strengthening of cooperative regeneration, especially among the younger generation and other productive groups; 6) Improving the conducive business climate through the establishment and improvement of regulations and policies, the ease of licensing, as well as increased opportunities, certainty and business protection and 7) Increased integration of inter-agency and central-regional policies supported by other stakeholders.

The above efforts will be achieved through the model proposed in this study. The main purpose of this model is to absorb unemployment and poverty, and to empower it to avoid any economic disparities among the people of Indonesia. However, it is important for the SME Ministry to continue maturing with the Amil Zakat Institution and Sharia Banking in establishing the appropriate criteria for the people who deserve to be given productive zakat funds. This is very important so then the sustainability and success of the model can be achieved. In addition, there should be cooperation by bringing together the co-workers from the Ministry of Cooperative, and Small and Medium Enterprises to prevent no more cases of errors in giving productive zakat. Therefore, the assistance of the Ministry of Cooperatives and Small Medium Enterprises is truly vital in determining the credibility of an entrepreneur initiated through the productive zakat program in this model.

\section{The Role of Sharia Banking in Islamic Financial Inclusion Models}

Sharia banking is an important institution in implementing financial inclusion in Indonesia. In 2008, the number of sharia banking industries at that time still amounted to 155 . There are 3 Sharia Commercial Bank (BUS), 28 Sharia Business Unit (UUS), and 124 Sharia Rural Banks (BPRS). Now that number is increasing with the increasing public awareness of using non-interest financial products. In December 2013, Indonesia already had 11 Sharia Commercial Banks (BUS), 23 Sharia Business Units (UUS), and 16 Sharia Rural Financing Banks (BPRS). This shows that sharia banking is able to survive and grow despite economic instability, such as the crisis of 1998, 2008 and the crisis that hit Europe in the last year.

However, in terms of product performance, Sharia Banks still struggling on the sale of products within the sale and purchase agreement (murabaha). While the sale of products with a contract other than buying and selling has not been done (Muhammad, 2005), one of the major pillars of the implementation of sharia economy in the banking world is mudaraba (profit sharing). This type of transaction represents the Islamic principle of realising community justice through a profit-sharing system. The issue of the low proportion of mudaraba compared to, for example murabahah, has long been a concern. Adnan (2007) reviewed it, and even tried to provide alternative solutions. However, reality has not changed much. This issue continues to this day. As Rahardjo (2014) stated in the daily column of Kompas Feb. Edition, Islamic banks in Indonesia get criticism related to the goal that tend to be investor-oriented as well as conventional banks because of three things: 1) 70 percent of sharia bank contracts are in the form of murabaha transactions and serve the needs of consumption and trade with the mark-up system while other products, especially qardul hasan for the poor and entrepreneurs, are very limited; 2) profit sharing received or charged to the debtor is higher than the interest rate and 3) concerns about the fall of sharia banks to foreign investors 
because the market share of sharia banks still reached only 5 percent of the national banking assets.

Muhammad (2005) explains that low-cost financing with mudaraba occurs due to moral standards, the ineffectiveness of profit-sharing models related to entrepreneurs, cost and technical aspects, unattractive profit-sharing systems in business activities, and efficiency issues. Neneng (2010) describes low funding within the mudaraba scheme as being due to the high risk contained in mudaraba. Especially in the case of financial inclusion, the direction toward sustainable cooperation access will not occur if the poor still do not provide promising prospects for sharia banking.

CSR needs to be maximised by sharia banks. CSR or corporate social responsibility is a business commitment to contribute to sustainable economic development, through collaboration with employees and their representatives, their families, local communities and the general public to improve quality of life in a way that is beneficial to both the business and for public development (Nurlela and Islahuddin, 2008). This optimisation of Islamic banking CSR can be either through free financial consultation services or by hiring financial consultants to help the way that the model has been proposed before. In the long-term, the results of CSR provided by sharia banks in the realisation of this model will provide feedback for sharia banking itself with the ability of the mustahik who were once unbankable to be eligible to have a formal banking account. They would even able to obtain financing by a cooperation scheme (mudaraba) which was previously very difficult.

\section{Islamic Financial Inclusion Model and Indonesian Economic Development}

This model is made by looking at the phenomenon of the Amil Zakat Institution that is mushrooming in the society. It gives an inefficient initial impression and requires a synergy of direction and order along with the purpose of the Indonesian government itself. In addition, there are still many doubts about the management of professional zakat with a marked small realisation of zakat's potential. In order to answer the challenge, with the existence of financial inclusion to alleviate the poverty of the country, there needs to be a cooperative model that synergises well and is committed. By involving the governmental sector, the private sector and society, this model is built on the strength of brotherhood and humanity that exists in society which, according to Ibn Khaldun in Chapra (2008), is one of the factors that supports the existence of justice. The real output resulting from this model is in the form of indicators of development itself, namely the decline in poverty and unemployment, an increase in the per capita income that can lead to the fulfilment of more prosperous life needs such as education and health, and the possibility of economic openness through an increase in exports due to the growth of the MSMEs sector in Indonesia.

\section{Conclusion}

The cooperation between several parties in order to achieve economic development is needed. It is important to assess all Indonesian institutions functionally and structurally regarding creating a synergetic model. The integrated model in this study involves the cooperation of three sectors which have different agendas but the same purpose; welfare. The sectors are the government, private (banking), and non-profit organisations. The implementation of this model under the right arrangement of rules, steps and direction will ensure economic development success. Later on, economic development can be seen from reducing poverty, unemployment, the Gini index, and increasing exports/imports, economic openness and the human development index.

\section{Suggestion}

Based on the discussion and conclusion, it can be suggested that every institution can synchronise their rules regarding the same purpose: Indonesia economic development and poverty reduction. The authors have also given some suggestions for further research that include:

1. This study used only a library research method; it is expected for future research that researchers can use other research methods that are more in-depth to have more accurate results.

2. Future research may involve more related institutions.

\section{References}

[1] Adnan, M. A. 2007. Toward an Idal Balance of Islamic Banking Products Portfolio: The Case of the Syariah Bank Industry in Indonesia, dalam Nafis Alam dan Bala Shanmugam (Eds), Islamic Finance, The Challenges Ahead. Serdang: Univeisti Putra Malaysia Press.

[2] Asian Development Bank. 2016. Basic Statistics 2016: Development Economics and Indicators Division.

[3] Arsyad, L., 1999. Pengantar Perencanaan dan Pembangunan Ekonomi Daerah. Yogyakarta: BPFE

[4] Badan Amil Zakat Nasional. 2013. Laporan Tahunan BAZNAS.

[5] Beik, I. S. dan Arsyianti, L. D., 2016. Ekonomi Pembangunan Syariah. Jakarta: PT. RajaGrafindo Persada.

[6] Chapra, M. Umer. 2008. Ibn Khaldun's Theory of Development: Does It Help Explain The Low Performance Present-Day Muslim World?. The Journal of Socio-Economics, Vol. 37, h.836-863.

[7] Farwati, R., 2012. Pro-Poor Growth: Does it Work in Indonesia?. Erasmus University Rotterdam.

[8] Firmansyah, 2013. Zakat sebagai Instrumen Pengentasan Kemiskinan dan Kesenjangan Pendapatan. Jurnal Ekonomi dan Pembangunan, Vol. 21, No. 2 h. 179-190.

[9] Huda, et al., 2015. Ekonomi Pembangunan Islam. Jakarta: Kencana Prenadamedia Group.

[10] Karim, A. dan Syarief, A., 2008. Fenomena Unik di Balik Menjamurnya Lembaga Amil Zakat (LAZ) di Indonesia. Jurnal Pemikiran dan Gagasan, Vol. 1, No. 4, h. 42-49.

[11] Latief, H., 2008. Membangun Koherensi Antar Sektor: Filantropi Islam, Agenda Organisasi Sektor Ketiga dan Masyarakat Sipil di Indonesia. Jurnal Pemikiran dan Gagasan, Vol. 1, No. 4, h. 50-63.

[12] Levine, R., 2005. "Finance and Growth: Theory and Evidence." in P Aghion \& S. Durlauf, eds., Handbook of Economic Growth, 1st ed. Vol. 1, Chapt. 12, h. 537-558.

[13] Muhammad. 2005. Konstruksi Mudharabah Dalam Bisnis Syariah, Yogyakarta: BPFE.

[14] Nengsih, N., 2015. Peran Perbankan Syariah dalam Mengimplementasikan Keuangan Inklusif di Indonesia. Jurnal Etikonomi, Vol.14, No.2, h. 221-240.

[15] Nurlela, R., and Islahuddin. Pengaruh Corporate Social Responsibility Terhadap Nilai Perusahaan Dengan Prosentase Kepemilikan Manajemen Sebagai Variabel Moderating (Studi Empiris Pada Perusahaan Yang 
Terdaftar di Bursa Efek Jakarta). Simposium Nasional Akuntansi XI. Pontianak, 23-24 Juli 2008.

[16] Rahardjo, M. D. 2014. Kritik terhadap Perbankan Syariah. Harian Kompas: Edisi Februari. Kolom 7, h. 4-7.

[17] Setiawan, S., 2015. Financial Depth and Financial Access in Indonesia. Journal of Indonesian Economy and Business, Vol. 30, No. 2, h. 139158.

[18] Tambunan, T., 2015. Financial Inclusion, Financial Education and Financial Regulation: A Story from Indonesia. ADBI Working Paper Series, No. 535
[19] Zed, M., 2004. Metode Penelitian Kepustakaan. Jakarta: Yayasan Obor Nasional.

[20] Sujatmiko, 2005. Gaji dipotong, Seribu Guru di Lombok Timur Mogo Mengajar.

http://nasional.tempo.co/read/news/2005/12/01/05869968/gaji-dipotongseribu-guru-di-lombok-timur-mogok-mengajar, Accessed 16 Desember 2016 